\title{
PRELIMINARY STUDIES OF THE EFFECT OF DEOXI- DATION AND MOLD CONDITIONS ON THE TENSILE PROPERTIES OF CARBON STEEL CASTINGS ${ }^{1}$
}

\author{
By J. V. McCrae ${ }^{2}$ and R. L. Dowdell
}

ABSTRACT

Foundrymen occasionally experience difficulties with steel castings in meeting ductility specifications of 24 per cent elongation and 35 per cent reduction of area if the steel is deoxidized with aluminum shortly before pouring the castings. Sound castings can usually be obtained in dry sand molds without the addition of "deoxidizers" immediately before pouring.

Green sand molding is generally desired but porosity, as "pinholes," often occurs. Aluminum and other "deoxidizers" studied eliminated porosity but lowered the ductility. The mold conditions are probably the important variables responsible for pinholes. A sufficient amount of "deoxidizer," however, should be in the steel at the time of pouring to deoxidize the steel from the gases evolved from the moisture contained in the mold.

\section{CONTENTS}

I. Introduction............. 266

II. Plan of investigation

1. Preliminary tests

2. Foundry practice used in the production of test castings.-- 267

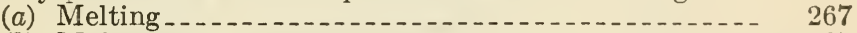

(b) Molds

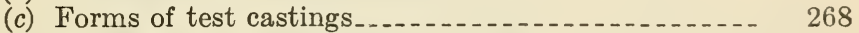

(d) Heat treatment................ 268

3. Test methods and equipment.

III. Results

268

268

269

270

270

270

270

271

271

271

2. Effect of various deoxidizers and deoxidation methods....- 271

(a) Aluminum (b) Special "deoxidizers",

3. Surface treatment of green sand molds............ 275

4. Effect of green sand control

IV. Summary ......... 276

1 This paper gives a short account of the research work which is to be published in the Transactions of the American Society for Steel Treating, 1931.

2 Research associate, the Steel Castings Development Bureau, (Mr, McCrae is now deceased.) 


\section{INTRODUCTION}

The problem of obtaining sound steel castings in green sand molds with the most desirable mechanical properties has long been studied by steel foundrymen. Frequently steel foundrymen are called on to meet specifications ${ }^{3}$ in which the minimum requirements are: Tensile strength, 60,000 lbs./in. ${ }^{2}$; yield point 45 per cent of the tensile strength; elongation on a 2 -inch gage length 24 per cent; and reduction of area 35 per cent.

These specifications can be generally fulfilled if dry sand or surfacedried molds are used, but green sand molds are desired in many cases. With green sand molds, it is frequently found that small holes, known as "pinholes," are frequently produced at fillets and similar positions on surfaces of castings. Most of the trouble seems to be due to the moisture in the green sand molds. These pinholes are apparently caused either by the moisture itself, as steam, or its dissociaton products or both.

While the addition of aluminum (about 1 pound per ton of steel) will usually eliminate the pinhole trouble, it will generally reduce the ductility of castings

Castings having low ductility persist even after heat treatment consisting of either normalizing or annealing from $900^{\circ}$ to $925^{\circ} \mathrm{C}$. $\left(1,650^{\circ}\right.$ to $1,700^{\circ} \mathrm{F}$.) followed by reheating to temperatures just below the $A c_{1}$ critical point or about $705^{\circ} \mathrm{C}$. (1,300 $0^{\circ} \mathrm{F}$.). When this problem was brought to the attention of the National Bureau of Standards, it was considered a suitable subject for study because the United States Government is a large purchaser of steel castings.

The work was undertaken, on the research associate plan, ${ }^{4}$ in cooperation with two founder members of the organization of the association which is now known as The Steel Castings Development Bureau.

\section{PLAN OF INVESTIGATION}

\section{PRELIMINARY TESTS}

The first series of tests was planned with the aim of determining the extent of the reported difficulties. In the early plans, it was decided to study consecutive heats from the different foundries. For this preliminary work, 100 consecutive heats were produced by one of the foundries, 32 heats (not all consecutive) by a second foundry.

The seriousness of the question of low ductility was well brought out by these preliminary experiments, and on discussing this problem of low ductility in steel castings with steel mill operators, it was found that this same problem is quite common with rolled and forged steels as well as with steel castings. It was evident, therefore, that in this study of steel castings all possible phases of the subject that might influence the results should be included. With this in mind the plan of study was outlined to include the effect of varying ordinary foundry conditions, such as green and dry sand molds, miscellaneous variables, such as segregation, design of test castings, heat treatment, casting temperature, character of scrap, various deoxidizers and deoxidization methods, and various mold conditions.

3 U. S. Navy Department Specifications 49S1G, April 1, 1925. Steel Castings (class B).

Burcau of standards Circular No. 296. 


\section{FOUNDRY PRACTICE USED IN THE PRODUCTION OF TEST CASTINGS}

\section{(a) MELTING}

The typical melting practices used by the two foundries are shown in Table 1. These practices which did not differ materially were closely adhered to with only slight changes which will be stated as the results of this investigation are discussed. A study of Table 1 shows that the two foundries used what is considered to be the normal melting practice on steel castings.

TABLE 1.-General foundry practices at the two acid electric stecl foundries in the production of the test castings

[All castings were poured over the lip of the ladle]

\begin{tabular}{|c|c|c|c|}
\hline & \multicolumn{3}{|c|}{ Plants- } \\
\hline & B & $A$ & A \\
\hline 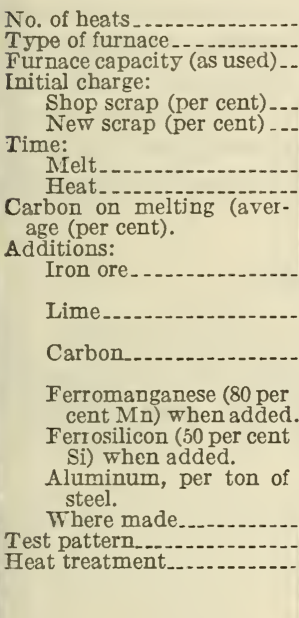 & 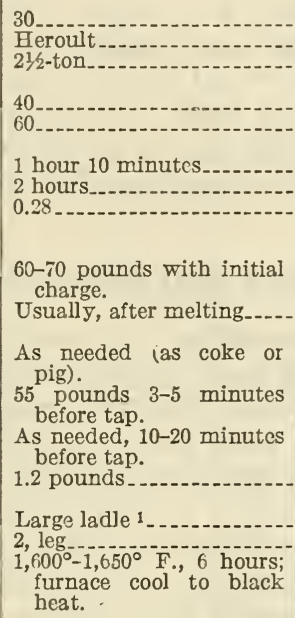 & 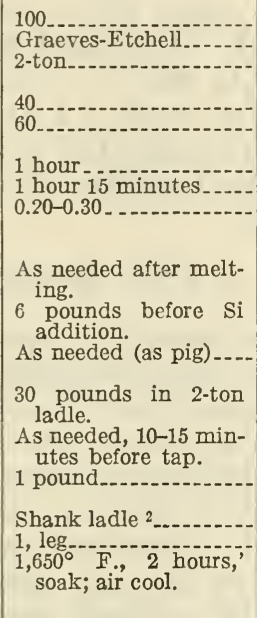 & $\begin{array}{l}29 . \\
\text { Graeves-Etchell. } \\
2 \text {-ton. } \\
40 . \\
60 . \\
1 \text { hour. } \\
1 \text { hour } 15 \text { minutes. } \\
0.20 \text { - } 0.30 . \\
\text { As needed after melt- } \\
\text { ing. } \\
\text { pounds before Si } \\
\text { addition. } \\
\text { As needed (as pig). } \\
35 \text { pounds in furnace } \\
\text { just before tap. } \\
\text { As needed, 10-15 min- } \\
\text { utes before tap. } \\
1 \text { pound. } \\
\text { Large ladle. } 1 \\
1, \text { leg. } \\
1,650^{\circ} \text { F., } 2 \text { hours,' } \\
\text { soak; air cool. }\end{array}$ \\
\hline
\end{tabular}

1 Ladle contains the entire charge.

2 Ladle contains only a pait of the charge.

The commercial production of acid electric steel castings is practically a plain melting operation with no attempt to refine to the degree which is practiced with basic lined furnaces. In the production of steel castings the scrap is selected so that its phosphorus and sulphur content are usually below 0.05 per cent each. The charge is melted; brought to the desired composition by suitable additions; deoxidized, either in the furnace or the ladle or both; tapped and poured into castings.

\section{(b) MOLDS}

Both green sand and dry sand molding were used by the plants in the preparation of test castings. The green sand molding conditions were about the same in the various plants.

At various times throughout the investigation, test castings were poured in cored molds and combinations of core and green sand molds. No attempt has been made to determine the sand characteristics of 
the cored molds. Also, during these experiments, various mold preparations, such as rubber compounds, alcohol, powdered aluminum, powdered magnesium, etc., were used. The results of these mold preparations are given later.

\section{(c) FORMS OF TEST CASTINGS}

All of the test castings were poured as "detached" castings. This form is not the same as the so-called "attached coupon bar." A modified form of test casting was used in the latter part of the investigation. This modification was used primarily to show how different surfaces of the same steel casting are affected by both core and green sand mold conditions.

\section{(d) HEAT TREATMENT}

Most steel foundries now heat treat their castings for commercial use in order to obtain the higher mechanical properties which the trade demands. The test castings were previously heat treated at the various foundries where they were cast. These treatments are shown in Table 1. In general, the heat treatment consisted of normalizing from $870^{\circ}$ to $900^{\circ} \mathrm{C}$. $\left(1,600^{\circ}\right.$ to $1,650^{\circ} \mathrm{F}$.) or annealing from the same temperature range to a black heat. Various heat treating experiments were also conducted in the course of this work with the hope of improving the ductility of the steels which had been deoxidized with aluminum.

\section{TEST METHODS AND EQUIPMENT}

The main test used for determining the mechanical properties of the test castings was the tensile test. Standard 0.505 inch diameter test bars were machined, after heat treating, from the test castings. The yield point was determined from the automatically drawn stressstrain curves which were determined in each case.

The Izod impact test was used to a very limited extent in a preliminary way to supplement the ductility values as measured by the tensile test. Only 16 bars were tested. The results showed that as the ductility of the castings increased there also was a slight tendency toward higher resistance to impact. However, the Izod determinations on steel castings were not considered to be discriminating enough to be of importance in this work.

\section{RESULTS}

\section{EFFECT OF VARYING ORDINARY FOUNDRY CONDITIONS}

(a) AVERAGE PROPERTIES OF GREEN SAND CASTINGS

No detailed data were available to show the chemical and physical properties and structural characteristics of the customary product in green sand castings, so a study was first made of 100 consecutive heats. The furnace charge for these consisted of about 20 per cent of boiler punchings, 15 per cent of light punchings from cold-rolled sheet, 25 per cent of heavy ball bearing punchings, and the remainder of return shop scrap (gates, heads, castings, etc.). After melting, small quantities of iron ore, lime, ferrosilicon, etc., were added as required, and after about 1 hour and 15 minutes, the metal was ready to cast. The heats were tapped into a 2-ton teapot ladle where the ferro- 
manganese was added. From this ladle the metal was poured into the working ladle, the capacities of which varied from 70 to 1,200 pounds of steel. All of the test castings were poured in duplicate or triplicate from a 70-pound ladle. Aluminum (1 pound per ton of steel) was added in this ladle and the metal immediately poured into the test molds. After normalizing, these were machined into tensile bars. The customary normalizing practice used for these heats consisted of heating two hours at $900^{\circ}$ C. $\left(1,650^{\circ}\right.$ F.), followed by air cooling.

The 100 heats are grouped according to carbon contents, as shown in Figure 1. It is apparent from this figure that the carbon content must be kept at low values, say, from 0.12 to 0.17 per cent, if the majority of the heats produced under the so-called "standard" melting and normalizing practice outlined above are to meet the specification requirements.

(b) PROPERTIES OF DRY SAND CASTINGS

Tensile tests were made on dry sand castings selected at random from 32 heats containing approximately 0.20 to 0.30 per cent carbon. The castings were not made
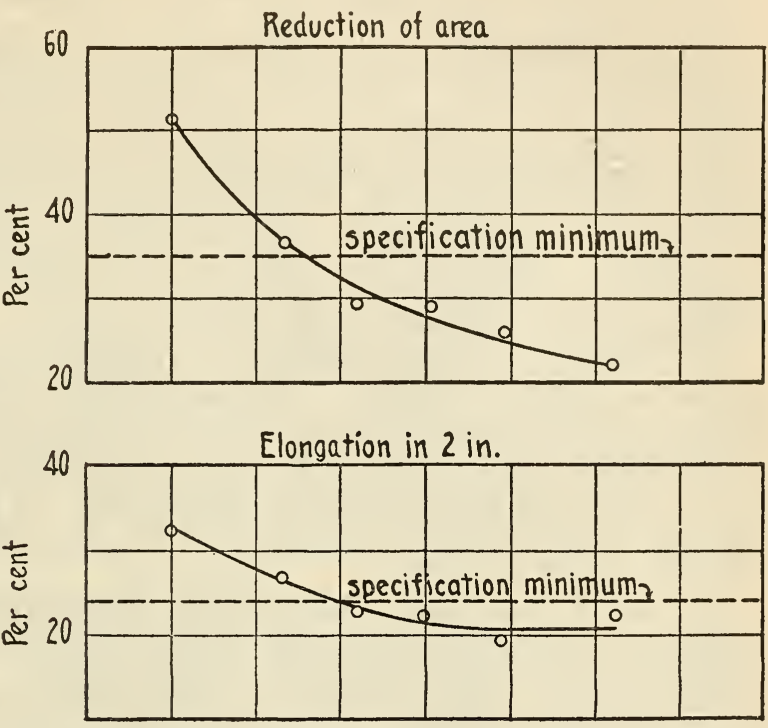

Tensile strength

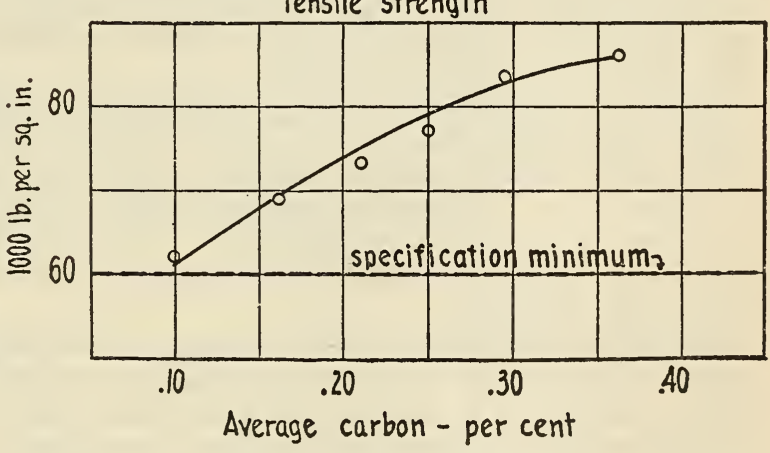

FigURE 1.-Relation of carbon content to mechanical properties of steel castings from 100 consecutive heats in plant production

Note.-Cast steel "deoxidized" immediately before pouring with the equivalent of 1 pound of aluminum per ton of steel added to shank ladle. Test castings made in green sand holes.

especially for the tests but were taken from heats made early in the course of this investigation by company "B." About one-fifth of the specimens representative of the 32 heats made by company "B" failed to meet the specification requirements of 35 per cent or more reduction of area and, in addition, about 5 per cent showed less than the required 24 per cent or more elongation in 2 inches. 
Microscopic examination showed that the dendritic or Widmanstatten structure characteristic of cast steel was more easily eliminated if the steel had been cast without the addition of aluminum immediately before pouring.

\section{(c) MISCELLANEOUS VARIABLES}

(1) Segregation.- Steel castings do not, in general, show so great a degree of structural, chemical, or physical homogeneity, as wrought steels and the variations encountered may be of considerable magnitude. Fractured tensile test specimens from heats originally reported to contain very nearly the same carbon, but which showed widely different values of elongation and reduction of area were selected for microscopic examination. Study of the individual test specimens indicated a considerable difference in carbon content which was subsequently confirmed by chemical analysis.

(2) Design of Test Castings.- - Another factor considered relates to the form of test casting. The one regularly used had sharp corners in the portions from which the tensile specimens are machined. Such corners affect the process of dendritic formation and may introduce a line of weakness extending into the test bar. It was found that slight changes in the form of test castings did not produce noticeable differences in the ductility.

(3) Heat Treatment.-Thermal analyses were made of two of the cast steels, since these normally contain somewhat higher silicon than commercial wrought steels of similar carbon contents. The $\mathrm{Ac}_{3}$ transformation temperature was considerably higher in both of the cast steels than in the low-silicon steels usually employed for rolled and forged products. On this account the first modifications made in the "standard" rormalizing cycle were to increase the temperature and decrease the rate of cooling.

Samples from heats which showed good tensile properties under "standard" normalizing and those which showed relatively poor tensile properties were quenched and subsequently tempered at $650^{\circ}$ C. $\left(1,200^{\circ}\right.$ F.). Prolonged soaking at high temperatures is helpful in breaking up dendritic segregation. Long heating at temperatures just under or in the transformation range has frequently been found to increase ductility.

Of the five variables in heat treatment investigated, only one, prolonged tempering at $1,300^{\circ} \mathrm{F}$., produced quite definite and appreciable improvement in the ductility of the steels. Increase in the temperature from which the steel was cooled, combined with a slower cooling rate (furnace cooling), was not effective in increasing the ductility of the samples. Water quenching followed by tempering at $650^{\circ} \mathrm{C}$. $\left(1,200^{\circ} \mathrm{F}\right.$.) did not bring the heats having low ductility within the requirements, although either a higher tempering temperature or a longer time of tempering might have produced a sufficient improvement. The use of water quenching, in general, followed by tempering would not appear to be practicable on account of the intricate design of the average foundry product.

One type of treatment which effectively raised the ductility was a tempering at $705^{\circ} \mathrm{C}$. $\left(1,300^{\circ} \mathrm{F}\right.$.) subsequent to normalizing. There was no marked change in ductility produced by tempering those heats 
which showed high elongation and reduction of area after simple normalizing, but the so-called poor heats showed a relatively large increase in both reduction of area and elongation when tempered for only two hours at $705^{\circ} \mathrm{C}$. $\left(1,300^{\circ} \mathrm{F}\right.$.).

A 15 -hour heating at $705^{\circ} \mathrm{C}$. $\left(1,300^{\circ} \mathrm{F}\right.$.) produced a considerable degree of spheroidization of the cementite which was accompanied by an increase in the elongation and reduction of area, although there was no appreciable change in the dendrites which were not removed by the simple normalizing.

(4) Casting Temperature.-The results from the 100 beats suggest that there is a tendency toward higher tensile properties if the castings are poured as hot as practicable. It was noted that results from additional heats, picked at random, were consistent with the general indications of the 100 consecutive heats previously reported.

(5) Character of Scrap Used in the Charge.- Several heats were made in which the character of the scrap was varied in order to study whether this factor bears any important relation to the ductility of the castings. The results indicated that the ductility of test castings poured in green sand ( 1 pound of aluminum per ton of metal added to the shank ladle before casting) was somewhat lower when light scrap was used in the charge rather than heavy scrap. In general, however, the question of the character of scrap used appears to play only a small part in the matter.

(6) Alloying With Either Nickel or Vanadium.-Two of the yeats containing about one-half and three-fourths per cent of nickel, respectively, showed a combination of good strength and ductility but it does not appear justifiable to attribute these properties solely to the nickel. Several of the other heats containing nickel showed very low ductility. Vanadium was also added to a 70-pound ladle of metal. This ladle of metal was divided, aluminum being added to one part but not to the other. One test bar from a casting containing 0.25 per cent $V$, without aluminum, showed good properties, but the corresponding bar was porous. It seems that the additions of low amounts of the usual alloy elements will not appreciably improve the ductility of steel castings made in green sand.

\section{EFFECT OF VARIOUS DEOXIDIZERS AND DEOXIDATION METHODS}

Numerous experiments were made to show the effect of different so-called deoxidizers on the tensile properties of steel castings when added in various ways and in different amounts. On account of the widespread use of aluminum in steel casting practice, attention was first given to the use of this deoxidizer. Later, experiments were made with other less familiar "deoxidizers." These tests should be regarded as "pilot tests." However, the general behavior of the "addition" was rather clearly indicated.

\section{(a) ALUMINUM}

In a considerable number of cases in this investigation sound castings were obtained when no aluminum was added. Indeed, the claim has been made that in normal foundry practice sound castings can be obtained without the use of aluminum for about 80 per cent of the time. 
Additional heats were made in which the same amount of aluminum was added to the steel, but the addition was made to the metal in the large ladle during tapping. A comparison of the results with those obtained on the 100 heats showed that, while the ductility values were somewhat low in a number of cases, they were not so low as the values obtained with the 100 heats. It would seem that the products of deoxidation have had a better chance to rise to the surface and, perhaps, free the steel more from colloidal particles which would affect the ductility. Many of these bars, however, contained blowholes, thus showing that the steels had not completely "degasified" or that bad mold conditions had actually "regasified" the metal which did not contain sufficient deoxidizer to allow for the gases evolved by the mold. There is indirect evidence that the greater these mold gases the higher will be the amount of aluminum necessary to insure soundness and the lower will be the ductility of the steel. The practice of deoxidizing with aluminum in the large ladle does not insure soundness in those cases where the metal is to be poured into a smaller ladle in order to pour small castings.

In general, "pinholes" were prevalent in the majority of the castings in which the practice was followed of adding the aluminum in the large ladle. Although no definite conclusions are justified on the basis of these results alone, it is apparent that the problem does not depend entirely upon the time when the aluminum additions are made with respect to the time of casting. Evidently the initial condition of the steel plays an important part. In this respect, they tended to duplicate the condition which so frequently obtains in castings made from steel which has not been treated with aluminum. The porosity may have resulted from an insufficient amount of residual deoxidizer to compensate for the gases formed from the moisture of the mold.

The results of tests carried out for the purpose of studying the effect of varying the amount of aluminum added to green sand castings are given in Figure 2. Two corresponding series of tests were carried out-one in the plant of company "A," the other at company "B." In the first series the amount of aluminum added was progressively increased up to 2 pounds per ton of steel, the additions being made in the "shank" ladle (70 pounds capacity). In the companion series (not shown in fig. 2) corresponding additions were used but were made in the large ( $21_{2}$-ton) ladle, the aluminum being added by fastening it to the end of a steel stirring rod and holding it beneath the surface of the metal. The test castings in this case were poured in approximately 12 minutes from a 150-pound capacity ladle which had been filled by pouring over the lip from the $2 \frac{1}{2}$-ton ladle.

It will be noted in Figure 2 that the tensile properties corresponding to zero addition of aluminum were very noticeably superior to those of any of the steels of the same series containing aluminum. These values are not readily attainable and are regarded somewhat as ideals or standards for comparison purposes rather than as results representative of general foundry practice.

As is evident from both series of tests, a relatively small addition of aluminum to the cast steel resulted in a marked change in the ductility properties of the steel. The decrease in the ductility, however, does not bear a linear rleationship to the amount of aluminum added. Both series of tests indicated a "ductility minimum" corre- 
sponding to a relatively early stage in the series of aluminum additions.

The results of both series of tests were in good agreement in showing that the effect of the progressive aluminum additions upon the tensile strength of the steel was relatively very much less than upon the ductility.

In the tests in which the aluminum was added in the large ladle, test castings were poured in both green sand and core sand. No important or singificant differences were obtained in the properties of the two sets of test castings prepared in this way.

\section{(b) SPECIAL DEOXI-
DIZERS}

In order to determine whether sufficient deoxidation could be secured without lowering the ductility of the steel if the aluminum were in combination, tests with a number of special deoxidizers were carried out. Compounds of aluminum, silicon, and iron were first used. One of these, Alsifer, is a commercial product. Three others were prepared for the tests
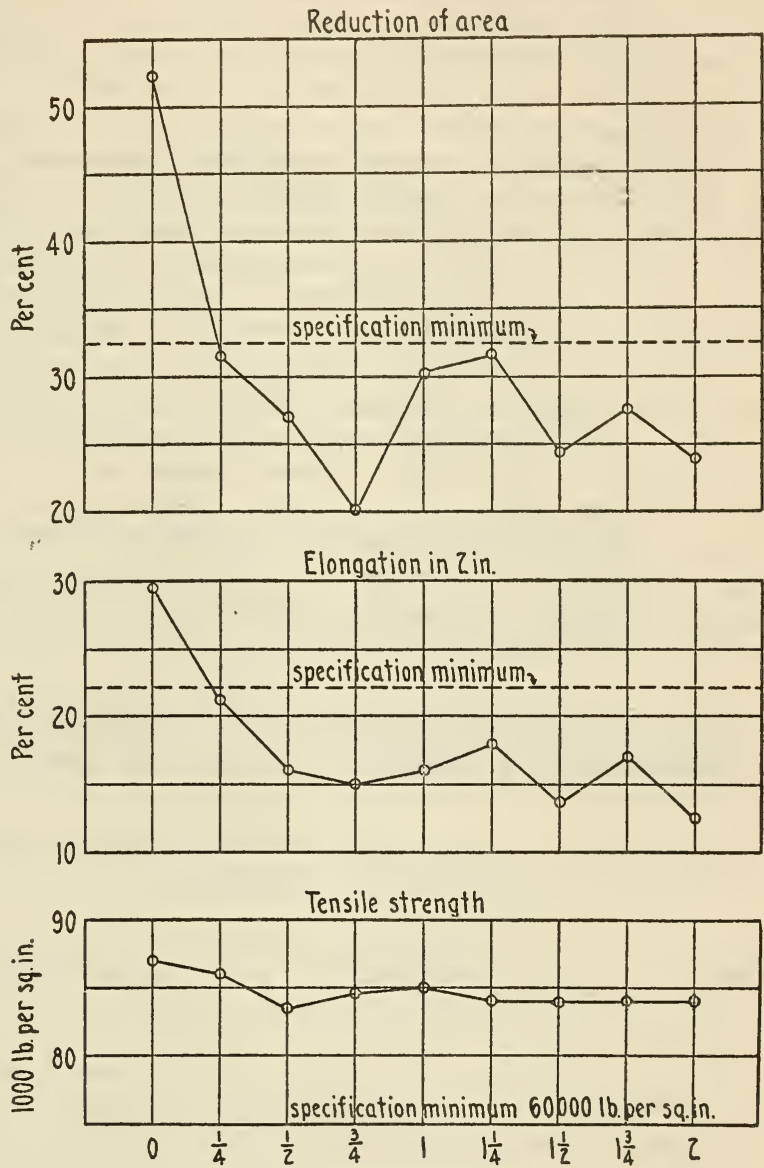

Aluminum content-pounds per ton of steel

FIGURE 2.-Effect of quantity of aluminum on mechanical properties of steel castings

Note.-Heat 5,680: Analysis C 0.26, Mn 0.63, Si 0.37 per cent. Aluminum added to shank ladle immediately before casting. Test castings made in green sand molds. Normalized at $900^{\circ} \mathrm{C}$. $\left(1,650^{\circ} \mathrm{F}\right.$.) two hours. Each point represents average of two tests.

at the Pittsburgh station of the Bureau of Mines, under the supervision of Dr. C. H. Herty.

A composite core sand and green sand mold was used for the test castings in which the gate, the end near the gate, and two-thirds of one side of the mold were made of core sand, the balance being rammed from green sand. With such a mold one face of the casting will 
illustrate the behavior of the metal in contact with green sand. At the same time the reduced section from which the tensile test bars are cut gives the properties of green-sand castings.

Some pinholes were found after chipping the casting at the fillets, but the only castings which showed an appreciable degree of porosity in the fillets were those made without the addition of aluminum. Porosity was found on the green-sand side. The same metal in contact with the core sand appeared to be perfectly sound.

While the particular heat selected for these experiments showed relatively low values of reduction of area when cast without the addition of aluminum, the results clearly indicated a reduction in the ductility upon adding aluminum either in the metallic form or as part of any of the four aluminum-silicon-iron alloys used. In general, the tests showed that the addition of each of the four aluminum-siliconiron alloys in amounts equivalent to 1 pound of aluminum per ton of steel produced sound castings, but lowered the ductility to about the same degree as did the addition of the aluminum alone.

Other additions which appeared to offer some possible promise as a deoxidizer were tried. Among these were an alloy of manganesesilicon-boron, alloys of alumnium, silicon, and boron, of several different compositions, metallic beryllium, an iron-aluminum alloy, and ferrotitanium. A number of rather unusual additions were also used, consisting of lead, brass (80 per cent copper, 20 per cent zinc), copper, zinc, and fused soda ash.

TABLE 2.-Effect on the tensile properties of steel test castings of a number of special deoxidizers, including aluminum, boron, boron-silicon-manganese alloy, aluminum-iron alloy, a mixture of ferrosilicon and ferromanganese, and carbon free ferrotitanium

[All castings were made in the combination green-sand and core-sand molds. Heat, $6983 ; \mathrm{C}, 0.23$ per cent. $\mathrm{Mn}, 0.66$ per cent, Si, 0.31 per cent; heat treated by normalizing at $900^{\circ} \mathrm{C}$. $\left(1,650^{\circ} \mathrm{F}.\right), 2$ hours.]

\begin{tabular}{|c|c|c|c|c|c|c|}
\hline $\begin{array}{l}\text { Speci- } \\
\text { men } \\
\text { No. }\end{array}$ & Additions 1 & $\begin{array}{l}\text { Yield } \\
\text { point }\end{array}$ & $\begin{array}{c}\text { Tensile } \\
\text { strength }\end{array}$ & $\begin{array}{l}\text { Elonga- } \\
\text { tion } \\
\text { in } 2 \\
\text { inches }\end{array}$ & $\begin{array}{c}\text { Reduc- } \\
\text { tion } \\
\text { of area }\end{array}$ & Remarks \\
\hline $83-2$ & Non & Lbs./in..$^{2}$ & Lbs./in. ${ }^{2}$ & Per cent & Per cent & \\
\hline $\begin{array}{l}4 \\
4 \mathrm{a}\end{array}$ & $\{1$ pound $\mathrm{Al}$ per ton of steel $(0.05$ per cent $\mathrm{Al})$. & $\left\{\begin{array}{l}35,000 \\
36,000\end{array}\right\}$ & $\begin{array}{l}70,500 \\
69,000\end{array}$ & $\begin{array}{l}30.0 \\
30.0\end{array}$ & $\begin{array}{l}46.0 \\
46.0\end{array}$ & $\begin{array}{l}\text { Sound. } \\
\text { Do. }\end{array}$ \\
\hline $\begin{array}{l}6 \\
6 \mathrm{a} \\
8 \\
8 \mathrm{a}\end{array}$ & $\left\{\begin{array}{l}1 / 2 \text { pound } \mathrm{Al} \text { per ton of steel }(0.025 \text { per cent } \mathrm{Al}) \text {. } \\
40 \mathrm{~g} . \text { alloy } \mathrm{D}^{2}(0.007 \text { per cent } \mathrm{B})\end{array}\right.$ & $\begin{array}{l}\left\{\begin{array}{l}39,000 \\
36,500\end{array}\right. \\
\left\{\begin{array}{l}33,500 \\
34,500\end{array}\right.\end{array}$ & $\begin{array}{l}71,000 \\
70,500 \\
71,600 \\
70,000\end{array}$ & $\begin{array}{l}31.0 \\
28.5 \\
20.0 \\
20.0\end{array}$ & $\begin{array}{l}51.5 \\
40.0 \\
18.0 \\
22.5\end{array}$ & $\begin{array}{l}\text { Do. } \\
\text { Do. } \\
\text { Do. } \\
\text { Do. }\end{array}$ \\
\hline $\begin{array}{l}10 \\
10 \mathrm{a} \\
12 \\
12 \mathrm{a}\end{array}$ & $\left\{\begin{array}{l}\text { Mixture of ferrosilicon and ferromanganese }{ }^{3} \\
70 \text { g. alloy } \mathrm{F}^{2}(0.05 \text { per cent } \mathrm{B}, 0.06 \text { per cent } \mathrm{Si}, 0.10 \\
\text { per cent } \mathrm{Mn})\end{array}\right.$ & $\begin{array}{l}\left\{\begin{array}{l}30,000 \\
38,500\end{array}\right. \\
\left\{\begin{array}{l}38,000 \\
39,000\end{array}\right.\end{array}$ & $\begin{array}{l}70,000 \\
72,000 \\
62,500 \\
67,000\end{array}$ & $\begin{array}{r}26.0 \\
34.0 \\
6.0 \\
10.0\end{array}$ & $\begin{array}{r}40.0 \\
51.0 \\
6.0 \\
10.0\end{array}$ & $\begin{array}{l}\text { Do. } \\
\text { Do. } \\
\text { Do. } \\
\text { D?. }\end{array}$ \\
\hline $\begin{array}{l}14 \\
14 \mathrm{a} \\
16 \\
16 \mathrm{a}\end{array}$ & $\left\{\begin{array}{l}40 \mathrm{~g} . \mathrm{FeAl}^{4}(0.06 \text { per cent } \mathrm{Al}) \\
30 \mathrm{~g} . \mathrm{C} \text { free } \mathrm{FeTi}^{2}(0.025 \text { per cent } \mathrm{Ti})\end{array}\right.$ & $\begin{array}{l}\left\{\begin{array}{l}35,500 \\
36,000\end{array}\right. \\
\left\{\begin{array}{l}38,000 \\
39,500\end{array}\right.\end{array}$ & $\begin{array}{l}67,000 \\
67,000 \\
68,000 \\
68,000\end{array}$ & $\begin{array}{l}20.0 \\
20.0 \\
18.5 \\
19.0\end{array}$ & $\begin{array}{l}22.0 \\
28.0 \\
18.0 \\
21.5\end{array}$ & $\begin{array}{l}\text { Do. } \\
\text { Do. } \\
\text { Do. } \\
\text { Do. }\end{array}$ \\
\hline
\end{tabular}

1 Additions were made in the 70-pound ladle.

2 Chemical composition of alloys:

$\mathrm{D}$

FeTi-approximately 28 per cent $\mathrm{Ti}$

Boron Si Mn

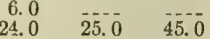

Additions equivalent of 0.05 per cent Si and 0.10 per cent $\mathrm{Mn}$ in the steel.

4 FeAl made by melting 10 pounds of aluminum and placing pot on the scales, then adding 10 pounds of molten steel, allowed to cool without stirring. 
Aluminum, boron, and silicon alloys of three different compositions were used, and for comparison the results obtained by adding aluminum in the ordinary manner and also the results of one series in which metallic beryllium was used as the deoxidizer. It was noted that the bars treated with the aluminum-boron-silicon alloy though sound were exceedingly low in their tensile properties while those of the beryllium-treated bars were only on a par with the aluminum treated ones.

The effect upon the tensile properties of steel castings produced by a number of special additions, including boron, a boron-manganesesilicon alloy, a mixture of ferrosilicon and ferromanganese, an aluminum-iron alloy and carbon-free ferrotitanium is shown in Table 2. Of the various additions, the mixture of ferrosilicon and ferro manganese was the only one which appeared to be promising.

The results obtained with an addition of zirconium (added as ferroziroonium to a $2 \frac{1}{2}$-ton ladle) of 0.10 pound per ton of steel were favorable from the standpoint of porosity, but the ductility of the steels was decreased about the same as with aluminum addition of 1 pound per ton.

\section{SURFACE TREATMENT OF GREEN-SAND MOLDS}

As stated at the outset, by the use of dry sand molds in steel-casting work, porosity difficulties are reduced to a minimum. A few experiments were carried out for the purpose of showing whether or not, by suitable mold preparations, the difficulties accompanying the use of green-sand molds could be overcome by eliminating or counteracting the effect of the moisture in such molds. The mold preparations used consisted of various surface treatments. It was noted that the test specimens were porous in a good many cases.

\section{EFFECT OF GREEN-SAND CONTROL}

From the beginning of this investigation it was believed that variables in green-sand practice, especially moisture, were largely responsible for the difficulties encountered from pinholes in most steel foundries. It was thought, however, that sand control would be harder to maintain to a high degree than would some suitable deoxidizer which might insure soundness without impairing ductility: The early work on deoxidizers, however, was not especially promising, so the effect of sand control was considered.

Instead of using a facing sand containing the usual amount of clay binder (bentonite), some of this binder was replaced by cereal bonds (corn flour and wheat flour) which varied between 0.2 and 0.6 per cent by volume, while the bentonite varied between 0.4 and 0.8 per cent. Molasses water, consisting of one part molasses to three parts of water, was used for tempering.

The tensile properties of test bars from 12 heats showed that little difficulty was encountered from porosity or low ductility when the moisture and permeability of the sand was closely controlled and when the carbon content of the heats varied between 0.18 and 0.25 per cent. The six heats from foundry "B" had higher ductility after the heat treatments than those from foundry "A." Aluminum was added in both cases, but less was added to the heats from foundry "B"; also this foundry made the additions to the large ladle by the submersion 
method previously described. This allowed more efficient deoxidation and also more time for the deoxidation products to escape from the metal which may have been the reason for the increased properties.

\section{SUMMARY}

1. The tensile properties frequently specified for acid electric steel castings, as minimum requirements, are an ultimate tensile strength of $60,000 \mathrm{lbs}$./in. ${ }^{2}$, and an elongation in a 2-inch gage length of 24 per cent, and 35 per cent reduction of area. Test castings made in dry-sand molds usually meet these requirements, but castings often lack soundness. This difficulty is usually overcome by the addition of a deoxidizer, usually aluminum, shortly before pouring, but the test castings not infrequently fail to meet the requirements with respect to ductility. The tensile properties and soundness of test castings of acid electric steel made in several steel foundries under a variety of conditions have been studied at considerable length as a basis of an investigation of this problem.

2. A survey of the field was made by the study of 100 consecutive heats in one foundry and 32 made in another. The tendency toward low ductility is related to the carbon content of the steel. This preliminary survey indicated that if the carbon content is between 0.10 and 0.17 per cent, manganese between 0.60 and 0.70 per cent, and silicon between 0.30 and 0.40 per cent, the addition of about 1 pound of aluminum per ton of steel to the ladle shortly before pouring will not lower the ductility of the normalized castings below the usual limitation.

3. Moderate changes in the variables in ordinary acid electric steel foundry practice have little effect with respect to low ductility of the steel. The size and character of the scrap used in the charge have no appreciable effect. Additions of nickel and of vanadium in moderate amounts do not appear to improve the ductility. Heat treatment, aside from rather pronounced changes involving quenching and tempering, appeared to have no appreciable effect upon the low ductility. A higher normalizing temperature-for example, $1,100^{\circ} \mathrm{C}$. $\left(2,000^{\circ}\right.$ F.) instead of $900^{\circ}$ C. $\left(1,650^{\circ}\right.$ F.) - appeared beneficial. A rather high casting temperature also appears desirable.

4. Of the numerous additions used as possible deoxidizers, including ferro-alloys of boron, zirconium, silicon, aluminum, and titanium, none were superior to aluminum. Most deoxidizers used were found to have a marked effect in reducing the ductility of the steel.

5. The effect upon the ductility of steel when aluminum is added is not a linear relationship. The amount of aluminum necessary to insure soundness in green-sand molds without seriously impairing the ductility may vary for different steel according to the melting practice, the mold condition, and the state of oxidation of the steel. It is believed, however, that a sufficient amount of deoxidizer should be in the steel at the time of pouring to deoxidize the steel from the gases evolved by the green sand. Usually about one-half pound of aluminum per ton of steel in the form of metallic aluminum or as an alloy of aluminum will give sound castings which, after normalizing, will show ductility somewhat higher than the specified minimum. If aluminum is added during tapping, the castings may be somewhat porous. The addition of at least part of the aluminum immediately 
before pouring is recommended. Although there is no definite proof, the inference from this work that inclusions of $\mathrm{Al}_{2} \mathrm{O}_{3}$ are largely responsible for the low ductility resulting when aluminum is added to the steel shortly before casting would seem to be justified.

6. The results of a few experiments with mold preparations in the form of surface treatments for counteracting the influence of the moisture in green-sand molds indicated that this method has merit, but the results were not especially promising.

7. The situation as regards porosity can generally be improved and the difficulties often overcome by controlling the mold conditions as regards moisture and permeability. By this method the minimum of aluminum or other deoxidizers is required to compensate for the gases evolved by the mold. If the carbon content is about 0.20 per cent, it will then be easier to meet the ductility specifications.

\section{ACKNOWLEDGMENTS}

The authors wish to express their appreciation and thanks to the Steel Castings Development Bureau and to George Batty, director of research of that bureau, for their interest throughout this investigation. Previous to the organization of the Steel Castings Development Bureau, the most hearty cooperation and support was given by the following persons: Clarence Tolan, jr., and C. S. Roberts, of Dodge Steel Co.; H. C. H. Cunningham and C. R. H. Cunningham, of Crucible Steel Casting Co. We also wish to express our sincere appreciation to H. S. Rawdon, chief of the division of metallurgy, and to Dr. H. W. Gillett, former chief of the division of metallurgy of the Bureau of Standards, for their helpful suggestions; to H. J. French, formerly of the Bureau of Standards, for directing the early part of the investigation; to the metallurgical staff as a whole, but more especially to H. K. Herschman, S. J. Rosenberg, L. Jordan, and C. M. Saeger, jr. We also wish to extend our appreciation to Dr. C. H. Herty, jr., and J. M. Gaines, jr., of the Bureau of Mines, for cooperation and helpful suggestions.

Washington, April 1, 1930. 